\title{
Communication \\ Cumulative Severity of Thinned and Unthinned Forests in a Large California Wildfire
}

\author{
Chad T. Hanson
}

Citation: Hanson, C.T. Cumulative Severity of Thinned and Unthinned Forests in a Large California Wildfire. Land 2022, 11, 373. https://doi.org/ 10.3390/land11030373

Academic Editors: Edward Morgan and Benjamin Burkhard

Received: 31 January 2022

Accepted: 1 March 2022

Published: 3 March 2022

Publisher's Note: MDPI stays neutral with regard to jurisdictional claims in published maps and institutional affiliations.

Copyright: (C) 2022 by the author. Licensee MDPI, Basel, Switzerland. This article is an open access article distributed under the terms and conditions of the Creative Commons Attribution (CC BY) license (https:// creativecommons.org/licenses/by/ $4.0 /)$.
Earth Island Institute, 2150 Allston Way, Suite 460, Berkeley, CA 94704, USA; cthanson1@gmail.com

\begin{abstract}
Studies pertaining to fire severity in commercially thinned versus unthinned forests are based on a comparison of tree mortality between the two categories. Commercial thinning is widely conducted on public and private forestlands as a fire management approach designed to reduce fire severity and associated tree mortality. However, tree mortality from thinning itself, prior to the occurrence of the wildfire, is generally not taken into account, which leaves a potentially important source of tree loss, with its associated forest carbon loss and carbon emissions, unreported. This study investigated the "cumulative severity" of commercially thinned and unthinned forests in a large 2021 wildfire, the Antelope fire, occurring within mixed-conifer forests on public lands in northern California, USA. Using published data regarding the percent basal area mortality for each commercial thinning unit that burned in the Antelope fire, combined with percent basal area mortality due to the fire itself from post-fire satellite imagery, it was found that commercial thinning was associated with significantly higher overall tree mortality levels (cumulative severity). More research is needed, in other large forest fires, to determine whether the finding, that commercial thinning killed more trees than it prevented from being killed, is common elsewhere.
\end{abstract}

Keywords: fire severity; wildfire; mixed conifer; forests; commercial thinning

\section{Introduction}

Research regarding commercial thinning and fire severity in conifer forests of the western USA is highly variable. Some studies have reported somewhat lower overall severity in commercially thinned forests [1,2], and others have reported mostly higher fire severity with commercial thinning [3,4]. If forest basal area removed by thinning, prior to fire, was nominal, such research could simply be compared and debated based on the methods and results. However, unlike noncommercial thinning that generally removes only seedlings up to trees slightly larger than saplings, commercial thinning often removes substantial portions of live-tree basal area prior to occurrence of wildfires, including many mature and old conifers [5], and this tree mortality from thinning is rarely accounted for in current research.

As fire severity in forests is fundamentally a metric pertaining to the level of tree mortality [6,7], there is reason to understand cumulative tree mortality, and "cumulative severity", from thinning and wildfire, in order to determine whether the result of thinning is more, or fewer, live trees in the landscape. This is particularly true in light of plans to substantially increase the pace and scale of commercial thinning of western U.S. forests as a fire management and forest resilience strategy. For example, recently, the U.S. Agriculture Department announced a $\$ 50$ billion plan to commercially thin approximately 50 million acres of forest over the following decade, mostly on public lands, as a wildfire strategy predicated upon the notion that this will reduce tree mortality in forests and increase resilience in the face of climate change [8].

Yet commercial thinning and other logging practices play a large role in removing live trees and thus reducing forest carbon storage, which influences climate change $[9,10]$. Moreover, there are many native wildlife species that depend upon dense, mature, and 
old conifer forests, both before and after mixed-severity wildfires. Commercial thinning can adversely affect such species by degrading dense older forests that many imperiled species need for nesting or denning, while also reducing the quality of "complex early seral forest" habitat [11] by removing so many trees from forests that they may be deficient for many snag-dependent species when such areas later experience high-severity fire [12,13]. Therefore, there is an important need to understand the degree to which commercial thinning itself affects overall tree mortality in forests. If, for example, a given stand that was commercially thinned experienced $10 \%$ lower basal area mortality in a fire compared to an adjacent unthinned stand, but the thinning operation resulted in $30 \%$ basal area mortality before the fire occurred, observers focusing solely on fire severity would miss the overall cumulative impact on live trees and imperiled wildlife species that depend on denser stands of live trees. Cumulative severity, which captures the combined basal area mortality from thinning and wildfire, presents a more complete picture of the effects.

However, in many cases it may be difficult to determine tree mortality from thinning, for example, in cases where recorded estimates may not exist. Therefore, addressing this question depends upon wildfire occurring in a previously-thinned area for which specific data regarding tree mortality from thinning are publicly available.

This study investigated whether cumulative fire severity, based on percent basal area mortality from commercial thinning plus percent basal area mortality from subsequent wildfire, would be different in thinned versus unthinned forests, using fire severity data from the 2021 Antelope fire in northern California in combination with pre-fire published data on tree mortality from commercial thinning in the same area, as described in the methods and results and contextualized in the discussion below.

\section{Materials and Methods}

I analyzed 15 commercial thinning units and adjacent unthinned forests in a portion of the Goosenest Adaptive Management Area in the Klamath National Forest in northern California (Figure 1). The study area is comprised of mixed conifer forest, dominated by white fir (Abies concolor), ponderosa pine (Pinus ponderosa), sugar pine (Pinus lambertiana), and incense cedar (Calocedrus decurrens), with smaller amounts of red fir (Abies magnifica) and lodgepole pine (Pinus contorta) in some areas $[14,15]$. Elevation in the study area ranges from $1460 \mathrm{~m}$ to $1515 \mathrm{~m}$.

The study area was heavily logged (mostly selective logging focusing on pine removal) in the 1920s and 1930s. Commercial thinning in the 15 units occurred 1998-2000, with prescribed fire occurring in 5 of the 15 units in 2001 (no post-thin burning occurred in the other 10 units). Each thinning unit was 40.49 ha in size. At the time of thinning, 5 control (no thinning) units of the same size were also established (Figure 1). Forests outside of the 20 units had a mix of thinning and other logging activities in some areas and no contemporary-era thinning or other logging (i.e., no logging since the 1920s and 1930s) in other areas. The locations and shapes of each unit are from Ritchie $(2005,2020)[14,15]$.

In August of 2021, the 58,935-ha Antelope lightning fire burned through the Goosenest Adaptive Management Area, including the 20 units in the study area. For each of the 15 commercial thinning units, I analyzed "cumulative severity" at pairs of locations $150 \mathrm{~m}$ inside and $150 \mathrm{~m}$ outside of the thinning units at the midpoint of each side of the units (Figure 1). I defined cumulative severity as percent basal area mortality from thinning (if any) for a particular location, plus percent basal area mortality of the remaining (after thinning) live tree basal area due to the Antelope fire. For example, if basal area mortality from commercial thinning was $20 \%$, and basal area mortality of the remaining $80 \%$ of live tree basal area was $50 \%$, then cumulative severity for such a location would be $20 \%+40 \%=60 \%$. Thus, cumulative severity presents a more comprehensive assessment of live tree mortality. Percent basal area removal (mortality) from commercial thinning at any location was determined based on the values for each unit reported in Ritchie (2005) [14], which ranged from $7 \%$ to $52 \%$ (mean $=32 \%$ ), depending on the unit. For the Antelope fire, I used the Rapid Assessment of Vegetation Condition after Wildfire (RAVG) satellite im- 
agery data (https: / fsapps.nwcg.gov / ravg/, accessed on 20 January 2022), which provides continuous data for percent basal area mortality from fire (i.e., specific numerical percent basal area mortality estimates for each pixel) at a $30 \mathrm{~m}$ resolution.

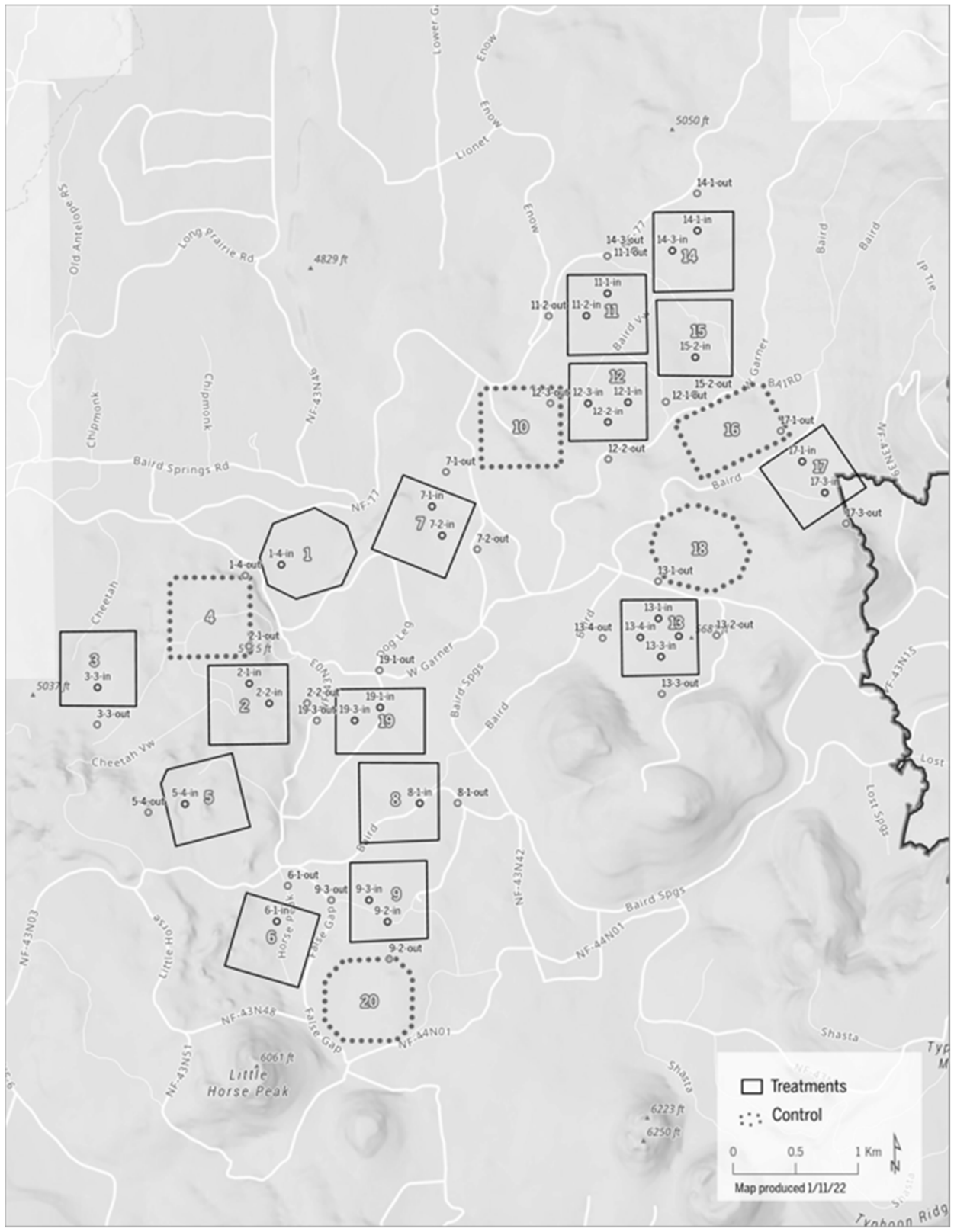

Figure 1. The Goosenest study area located within the Antelope fire of 2021, with plots and paired locations shown. The location of the study area within the larger landscape, and at the local scale, is shown in Figure 1 and Figure A1, respectively, of [14]. Unit numbers are shown in the center of each unit, and paired point locations are shown $150 \mathrm{~m}$ inside and $150 \mathrm{~m}$ outside of the thinning unit boundaries.

If any location (pixel) $150 \mathrm{~m}$ outside of thinning units burned on a different day from the corresponding paired location $150 \mathrm{~m}$ inside the thinning unit, I excluded these pairs. I also excluded pairs if the "outside" location had any evidence of pre-fire logging in the contemporary era. For this determination, I used satellite imagery from the National Agricultural Imagery Program (https:/ / www.fsa.usda.gov/programs-and-services/aerialphotography/imagery-programs / naip-imagery/, accessed on 20 January 2022). The im- 
agery was of sufficient quality to clearly see canopy cover reduction from tree removal due to logging, along with skid trails, logging roads, and landings.

I used a Chi-square test for differences in proportion [16] to evaluate whether it would be warranted to analyze plots with commercial thinning and no prescribed fire ("thin/no-burn") separately from plots with commercial thinning and prescribed fire ("thin/burn"). There was no significant difference between these two categories in terms of the proportion of plots with cumulative severity that was lower than unthinned forests $\left(\chi^{2}=0.094, d f=1, p=0.759\right)$. Therefore, I combined the two thinning categories into one category for statistical analysis purposes. This was warranted given that the Antelope fire did not burn differently in the commercial thin/no-burn units than it did in the commercial thin/burn units. I assessed whether there was a difference in cumulative severity between commercial thinning and no thinning using a Chi-square goodness of fit test [17].

\section{Results}

Commercial thinning locations had cumulative severity levels that were higher than adjacent unthinned locations significantly more often than the opposite effect $\left(\chi^{2}=6.26\right.$, $d f=1, p=0.012$ ). Overall, commercial thinning had higher cumulative tree mortality than corresponding unthinned areas in 20 out of 27 pairs of locations (Table 1). The mean cumulative percent basal area mortality in commercial thinning locations was $56.1 \%$, compared to $38.6 \%$ in corresponding unthinned forests (Table 1).

Table 1. Paired thinned/unthinned locations and whether cumulative severity was lower or higher in commercially thinned forests in the Goosenest study area within the Antelope fire of 2021.

\begin{tabular}{|c|c|c|c|c|}
\hline $\begin{array}{l}\text { Location } \\
\text { Identifier }\end{array}$ & $\begin{array}{c}\text { Thinning or No } \\
\text { Thinning }\end{array}$ & $\begin{array}{l}\text { Percent Basal Area } \\
\text { Mortality from } \\
\text { Thinning }\end{array}$ & $\begin{array}{l}\text { Cumulative Percent } \\
\text { Basal Area Mortality }\end{array}$ & $\begin{array}{c}\text { Thinned Location Lower } \\
\text { Cumulative Percent Basal } \\
\text { Area Mortality? }\end{array}$ \\
\hline 1-4-in & Thin (no burn) & 21 & 22 & Y \\
\hline 1-4-out & No Thin & 0 & 100 & \\
\hline 2-1-in & Thin (no burn) & 51 & 62 & $\mathrm{Y}$ \\
\hline 2-1-out & No Thin & 0 & 100 & \\
\hline 2-2-in & Thin (no burn) & 51 & 53 & Y \\
\hline 2-2-out & No Thin & 0 & 100 & \\
\hline 3-3-in & Thin (burn) & 39 & 94 & $\mathrm{~N}$ \\
\hline 3-3-out & No Thin & 0 & 89 & \\
\hline 5-4-in & Thin (no burn) & 28 & 96 & $\mathrm{~N}$ \\
\hline 5-4-out & No Thin & 0 & 73 & \\
\hline 6-1-in & Thin (burn) & 7 & 9 & $\mathrm{Y}$ \\
\hline 6-1-out & No Thin & 0 & 74 & \\
\hline 7-1-in & Thin (no burn) & 9 & 39 & $\mathrm{~N}$ \\
\hline 7-1-out & No Thin & 0 & 3 & \\
\hline 7 -2-in & Thin (no burn) & 9 & 86 & $\mathrm{~N}$ \\
\hline 7-2-out & No Thin & 0 & 35 & \\
\hline 8 -1-in & Thin (no burn) & 52 & 74 & $\mathrm{Y}$ \\
\hline 8-1-out & No Thin & 0 & 100 & \\
\hline 9-2-in & Thin (no burn) & 38 & 44 & $\mathrm{~N}$ \\
\hline 9-2-out & No Thin & 0 & 0 & \\
\hline
\end{tabular}


Table 1. Cont.

\begin{tabular}{|c|c|c|c|c|}
\hline $\begin{array}{l}\text { Location } \\
\text { Identifier }\end{array}$ & $\begin{array}{c}\text { Thinning or No } \\
\text { Thinning }\end{array}$ & $\begin{array}{l}\text { Percent Basal Area } \\
\text { Mortality from } \\
\text { Thinning }\end{array}$ & $\begin{array}{l}\text { Cumulative Percent } \\
\text { Basal Area Mortality }\end{array}$ & $\begin{array}{c}\text { Thinned Location Lower } \\
\text { Cumulative Percent Basal } \\
\text { Area Mortality? }\end{array}$ \\
\hline 9-3-in & Thin (no burn) & 38 & 96 & $\mathrm{~N}$ \\
\hline 9-3-out & No Thin & 0 & 0 & \\
\hline 11-1-in & Thin (no burn) & 29 & 45 & $\mathrm{~N}$ \\
\hline 11-1-out & No Thin & 0 & 0 & \\
\hline 11-2-in & Thin (no burn) & 29 & 55 & $\mathrm{~N}$ \\
\hline 11-2-out & No Thin & 0 & 49 & \\
\hline $12-1-$ in & Thin (no burn) & 22 & 100 & $\mathrm{~N}$ \\
\hline 12-1-out & No Thin & 0 & 17 & \\
\hline 12-2-in & Thin (no burn) & 22 & 74 & $\mathrm{~N}$ \\
\hline 12-2-out & No Thin & 0 & 52 & \\
\hline 12-3-in & Thin (no burn) & 22 & 31 & Y \\
\hline 12-3-out & No Thin & 0 & 100 & \\
\hline 13-1-in & Thin (burn) & 44 & 44 & $\mathrm{Y}$ \\
\hline 13-1-out & No Thin & 0 & 100 & \\
\hline 13-2-in & Thin (burn) & 44 & 44 & $\mathrm{~N}$ \\
\hline 13-2-out & No Thin & 0 & 0 & \\
\hline 13-3-in & Thin (burn) & 44 & 44 & $\mathrm{~N}$ \\
\hline 13-3-out & No Thin & 0 & 0 & \\
\hline 13-4-in & Thin (burn) & 44 & 44 & $\mathrm{~N}$ \\
\hline 13-4-out & No Thin & 0 & 0 & \\
\hline 14-1-in & Thin (no burn) & 23 & 24 & $\mathrm{~N}$ \\
\hline 14-1-out & No Thin & 0 & 8 & \\
\hline $14-3-$ in & Thin (no burn) & 23 & 36 & $\mathrm{~N}$ \\
\hline 14-3-out & No Thin & 0 & 0 & \\
\hline 15-2-in & Thin (burn) & 17 & 17 & $\mathrm{~N}$ \\
\hline 15-2-out & No Thin & 0 & 0 & \\
\hline 17-1-in & Thin (burn) & 41 & 41 & $\mathrm{~N}$ \\
\hline 17-1-out & No Thin & 0 & 0 & \\
\hline $17-3$-in & Thin (burn) & 41 & 41 & $\mathrm{~N}$ \\
\hline 17-3-out & No Thin & 0 & 0 & \\
\hline 19-1-in & Thin (no burn) & 43 & 100 & $\mathrm{~N}$ \\
\hline 19-1-out & No Thin & 0 & 30 & \\
\hline 19-3-in & Thin (no burn) & 0 & 100 & $\mathrm{~N}$ \\
\hline 19-3-out & No Thin & 0 & 11 & \\
\hline
\end{tabular}

\section{Discussion}

Commercial thinning resulted in overall higher levels of tree mortality, as compared to unthinned forests, when tree mortality from both thinning and the Antelope fire were combined. Accounting for the tree mortality from commercial thinning, prior to the occurrence of the 2021 Antelope fire, provided a more contextualized and complete assessment of the cumulative effects of this type of forest management on tree mortality. If percent basal area 
mortality from thinning had not been considered, and only tree mortality from the Antelope fire had been used, it could have created misleading results, given that fire-only mean basal area mortality was $34.7 \%$ in commercial thinning locations and $38.6 \%$ in unthinned locations. Without accounting for tree mortality from thinning, one might erroneously conclude from the fire-only data that thinning was slightly effective in maintaining live-tree cover and basal area in the Goosenest Adaptive Management Area.

There are substantial impacts to imperiled and endangered wildlife species that depend in part on dense mature/old forests, such as the California spotted owl (Strix occidentalis occidentalis), Pacific marten (Martes caurina), and Pacific fisher (Pekania pennanti), resulting from commercial thinning [18-20]. If commercial thinning, conducted as a fire management strategy, kills more trees than it prevents from being killed by wildfires, such impacts would be hard to justify from a biodiversity conservation standpoint.

Similarly, if thinning kills more trees than it prevents from being killed in wildfires, the climate change implications of this would need to be considered. For example, even when the assumption is made that commercial thinning will effectively reduce fire severity, one analysis, using field-based data, indicated that it results in three times the greenhouse gas emissions per hectare than wildfire alone [21].

More research is needed, in additional large fire areas, to determine how broadly the findings in the Antelope fire may apply to other areas in terms of cumulative severity.

Funding: This research was funded by the Environment Now foundation (grant \#2021).

Data Availability Statement: All data are either presented here or are available at the links in the Methods (for GIS data). Additional details on the commercial thinning units can be found in Ritchie $(2005,2020)[14,15]$.

Acknowledgments: I thank the reviewers, and GreenInfo Network for GIS work in Figure 1.

Conflicts of Interest: The author declares no conflict of interest. The funders had no role in the design of the study; in the collection, analyses, or interpretation of data; in the writing of the manuscript, or in the decision to publish the results.

\section{References}

1. Lydersen, J.M.; Collins, B.M.; Brooks, M.L.; Matchett, J.R.; Shive, K.L.; Povak, N.A.; Kane, V.R.; Smith, D.F. Evidence of fuels management and fire weather influencing fire severity in an extreme fire event. Ecol. Appl. 2017, 27, 2013-2030. [CrossRef] [PubMed]

2. Johnson, M.C.; Kennedy, M.C. Altered vegetation structure from mechanical thinning treatments changed wildfire behaviour in the wildland-Urban interface on the 2011 Wallow Fire, Arizona, USA. Int. J. Wildland Fire 2019, 28, 216-229. [CrossRef]

3. Cruz, M.G.; Alexander, M.E.; Dam, J.E. Using modeled surface and crown fire behavior characteristics to evaluate fuel treatment effectiveness: A caution. For. Sci. 2014, 60, 1000-1004. [CrossRef]

4. Hanson, C.T. Is "Fuel Reduction" Justified as Fire Management in Spotted Owl Habitat? Birds 2021, 2, 395-403. [CrossRef]

5. USDA. Amendments to Forest Service and Bureau of Land Management Planning Documents within the Range of the Northern Spotted Owl, Record of Decision ("Northwest Forest Plan"); USDA Forest Service, Pacific Northwest Region: Portland, OR, USA, 1994.

6. Miller, J.D.; Thode, A.E. Quantifying burn severity in a heterogeneous landscape with a relative version of the delta Normalized Burn Ratio (dNBR). Remote Sens. Environ. 2007, 109, 66-80. [CrossRef]

7. Miller, J.D.; Safford, H.D.; Crimmins, M.; Thode, A.E. Quantitative evidence for increasing forest fire severity in the Sierra Nevada and Southern Cascade Mountains, California and Nevada, USA. Ecosystems 2009, 12, 16-32. [CrossRef]

8. USDA. Confronting the Wildfire Crisis: A Strategy for Protecting Communities and Improving Resilience in America's Forests; USDA Forest Service, Washington, DC Office: Washington, DC, USA, 2022.

9. Law, B.E.; Hudiburg, T.W.; Berner, L.T.; Kent, J.J.; Buotte, P.C.; Harmon, M.E. Land use strategies to mitigate climate change in carbon dense temperate forests. Proc. Natl. Acad. Sci. USA 2018, 115, 3663-3668. [CrossRef] [PubMed]

10. Hudiburg, T.W.; Law, B.E.; Moomaw, W.R.; Harmon, M.E.; Stenzel, J.E. Meeting GHG reduction targets requires accounting for all forest sector emissions. Environ. Res. Lett. 2019, 14, 095005. [CrossRef]

11. DellaSala, D.A.; Bond, M.L.; Hanson, C.T.; Hutto, R.L.; Odion, D.C. Complex early seral forests of the Sierra Nevada: What are they and how can they be managed for ecological integrity? Nat. Areas J. 2014, 34, 310-324. [CrossRef]

12. DellaSala, D.A.; Hanson, C.T. (Eds.) The Ecological Importance of Mixed-Severity Fires: Nature's Phoenix; Elsevier Inc.: Waltham, MA, USA, 2015. 
13. DellaSala, D.A.; Hutto, R.L.; Hanson, C.T.; Bond, M.L.; Ingalsbee, T.; Odion, D.; Baker, W.L. Accomodating mixed-severity fire to restore and maintain ecosystem integrity with a focus on the Sierra Nevada of California, USA. Fire Ecol. 2017, 13, 148-171. [CrossRef]

14. Ritchie, M.W. Ecological Research at the Goosenest Adaptive Management Area in Northeastern California; Gen. Tech. Rep. PSW-192; U.S. Department of Agriculture, Forest Service, Pacific Southwest Research Station: Albany, CA, USA, 2005; 120p.

15. Ritchie, M.W. Effects of thinning and prescribed fire in the Goosenest Adaptive Management Area in northeastern California. In The 2019 National Silviculture Workshop: A Focus on Forest Management-Research Partnerships; Pile, L.S., Deal, R.L., Dey, D.C., Gwaze, D., Kabrick, J.M., John, M., Palik, B.J., Schuler, T.M., Eds.; Gen. Tech. Rep. NRS-P-193; Department of Agriculture, Forest Service, Northern Research Station: Madison, WI, USA, 2020; pp. 193-206.

16. Zar, J.H. Biostatistical Analysis, 5th ed.; Prentice Hall: Upper Saddle River, NJ, USA, 2010.

17. Rosner, A. Fundamentals of Biostatistics, 5th ed.; Duxbury: Pacific Grove, CA, USA, 2000.

18. Garner, J.D. Selection of Disturbed Habitat by Fishers (Martes Pennanti) in the Sierra National Forest. Master's Thesis, Humboldt State University, Arcata, CA, USA, 2013.

19. Stephens, S.L.; Bigelow, S.W.; Burnett, R.D.; Collins, B.M.; Gallagher, C.V.; Keane, J.; Kelt, D.A.; North, M.P.; Roberts, L.J.; Stine, P.A.; et al. California spotted owl, songbird, and small mammal responses to landscape fuel treatments. BioScience 2014, 64, 893-906. [CrossRef]

20. Moriarty, K.M.; Epps, C.W.; Zielinski, W.J. Forest thinning changes movement patterns and habitat use by Pacific marten. J. Wildl. Manag. 2016, 80, 621-633. [CrossRef]

21. Campbell, J.L.; Harmon, M.E.; Mitchell, S.R. Can fuel-reduction treatments really increase forest carbon storage in the western US by reducing future fire emissions? Front. Ecol. Environ. 2012, 10, 83-90. [CrossRef] 